\title{
PENGARUH PENERAPAN GOOD CORPORATE GOVERNANCE TERHADAP PERILAKU ETIS DALAM PENGELOLAAN DANA BANTUAN OPERASIONAL SEKOLAH
}

\author{
Fauzan \\ Email : gus_zain2001@yahoo.com
}

\begin{abstract}
Abstrak : Penelitian ini bertujuan menguji pengaruh penerapan good corporate governance terhadap perilaku etis dalam pengelolaan Dana BOS SMP di Kota Malang. Jenis penelitian adalah survey. Populasinya adalah kepala sekolah SMP baik negeri dan swasta penerima Dana BOS. Ada 24 SMP Negeri dan 66 SMP Swasta penerima Dana BOS. Teknik pengambilan sampelnya adalah simple random sampling. Penelitian ini menggunakan metode analisis regresi linear berganda. Hasil analisis menunjukkan bahwa semua variabel independen secara simultan berpengaruh positif dan signifikan terhadap variabel dependen. Secara parsial, transparansi berpengaruh secara positif dan signifikan terhadap pengelolaan dana BOS. Akuntabilitas berpengaruh negative dan tidak signifikan terhadap pengelolaan dana BOS. Partisipasi masyarakat berpengaruh secara positif dan tidak signifikan terhadap pengelolaan dana BOS. Transparansi yang paling dominan mempengaruhi pengelolaan dana BOS.
\end{abstract}

Kata kunci : BOS, Good Governance, Akuntabilitas, Transparansi

\section{PENDAHULUAN}

Fenomena yang terjadi dalam perkembangan sektor publik di Indonesia dewasa ini adalah menguatnya tuntutan akuntabilitas atas lembaga-lembaga publik, baik di pusat maupun daerah. Paradigma reformasi di Indonesia ditandai dengan munculnya semangat demokratisasi, akuntabilitas, dan transparansi dalam setiap aspek kehidupan. Salah satunya adalah dalam sector pendidikan.

Isu strategis yang terus disuarakan oleh berbagai kalangan terhadap negeri ini diantaranya adalah tuntutan terhadap adanya good governance, dan akuntabilitas. Peningkatan iklim akuntabilitas pada sector public yang merupakan dimensi etis dari Good Corporate Governance. GCG merupakan kesehatan moral sebuah organisasi (Fleeming and McNamee, 2005).

Gerakan reformasi yang terjadi membawa keuntungan bagi masyarakat. Dengan kata lain, akuntabilitas birokrasi publik dan tata kelola yang baik (good corporate governance) akan menjadi titik krusial bagi arah perkembangan demokrasi di Indonesia. Untuk meningkatkan tata kelola yang baik dibutuhkan praktek dalam kerangka politik dan social (Wanyama dan Burton, 2009). Terdapat

Fauzan, adalah Dosen Prodi Akuntansi Universitas Kanjuruhan Malang 
suatu hubungan yang erat, bahwa akuntabilitas publik dan tata kelola yang baik, berarti tidak terlepas didalamnya akuntabilitas dan tata kelola yang baik bidang pendidikan.

Kebijakan pembangunan pendidikan dalam kurun waktu 2004-2009 meliputi peningkatan akses rakyat terhadap pendidikan yang lebih berkualitas melalui peningkatan pelaksanaan Wajib Belajar Pendidikan Dasar Sembilan Tahun dan pemberian akses yang lebih besar kepada kelompok masyarakat yang selama ini berkurang dapat menjangkau layanan pendidikan. Salah satu amanat rakyat kepada penyelenggara negara adalah mencerdaskan kehidupan bangsa. Upaya mencerdaskan kebidupan bangsa dalam tataran operasional adalah melalui pendidikan. Pendidikan dalam kaitannya dengan manusia sebagai pribadi dan sebagai anggota masyarakat adalah upaya pengembangan kepribadian agar mampu memenuhi kebutuhan pribadi dan menyumbangkan kemampuannya untuk masyarakat. Untuk menyelenggarakan pendidikan, pemerintah perlu menetapkan serangkaian kebijakan pendidikan. Ada tiga pilar kebijakan pendidikan yang telah ditetapkan yaitu: (a) Perluasan dan pemerataan akses pendidikan, (b) Peningkatan mutu, relevansi dan daya saing, (c) Tata kelola, akuntabilitas dan pencitraan publik.

Salah satu bentuk pendanaan pendidikan dasar yang signifikan dari sumber dana Anggaran Pendapatan dan Belanja Negara (APBN) adalah Bantuan Operasional Sekolah (BOS). Program Bantuan Operasional Sekolah (BOS) adalah suatu kegiatan yang merupakan realisasi atau implementasi kebijakan dalam perluasan dan pemerataan akses pendidikan, khususnya dalam mendukung program wajib belajar pendidikan dasar (Wajar Dikdas) sembilan tahun. BOS merupakan implementasi dari Undang Undang Nomor 20 tahun 2003 pasal 34 ayat 2 menyebutkan bahwa pemerintah dan pemerintah daerah menjamin terselenggaranya wajib belajar minimal pada jenjang pendidikan dasar tanpa memungut biaya serta wajib belajar merupakan tanggung jawab Negara yang diselenggarakan oleh lembaga pendidikan dari pemerintah daerah dan masyarakat.

Program BOS merupakan program nasional di bidang pendidikan yang menyerap anggaran besar dan langsung berhubungan dengan hajat hidup masyarakat luas. Program BOS bertujuan untuk meringankan beban masyarakat terhadap pembiayaan pendidikan dalam rangka wajib belajar sembilan tahun. Undang-Undang Nomor 20 Tahun 2003 Pasal 48 meletakkan perinsip pengelolaan dana pendidikan yang berdasarkan perinsip partispasi, transparansi, akuntabilitas publik, efisiensi, dan keadilan.

Dengan adanya program dana BOS, sekolah dituntut kemampuannya untuk dapat merencanakan, melaksanakan dan mengevaluasi serta mempertanggungjawabkan pengelolaan biaya-biaya pendidikan secara transparan kepada masyarakat dan pemerintah. Pengelolaan pembiayaan pendidikan akan berpengaruh secara langsung terhadap mutu pendidikan sekolah, terutama berkaitan dengan sarana prasarana dan sumber belajar.

Pengelolaan BOS tidak terlepas dari peran kepala sekolah dalam mengatur alokasi pembiayaan untuk operasional sekolah. Mulyasa (2006) menyatakan bahwa kepala sekolah profesional dituntut memiliki kemampuan memanajemen keuangan sekolah, baik melakukan perencanaan, pelaksanaan, 
maupun evaluasi dan pertanggungjawabannya. Aspek mendasar dari manajemen adalah perencanaan, dalam hal pembiayaan yang disebut penganggaran. Sa'ud dan Makmun (2009) menyatakan, Perencanaan merupakan proses penyusunan berbagai keputusan yang akan dilaksanakan pada masa yang akan datang untuk mencapai tujuan yang telah ditentukan. Hal ini menunjukkan bahwa kemampuan kepala sekolah merencanakan keuangan untuk rencana kegiatan beserta sumber daya pendukung lainnya yang ada di sekolah merupakan sesuatu yang sangat penting.

Permasalahan yang terjadi dalam pelaksanaan program BOS pada umumnya adalah masih kurangnya transparansi dan akuntabilitas dalam pengelolaan dana Bantuan Operasional Sekolah (BOS), padahal penggunaan dana tersebut mestinya melibatkan orangtua siswa sejak perencanaan hingga pelaporan. Hal ini diperkuat dari hasil penelitian Bank Dunia, sebagian besar orangtua siswa pernah mendengar adanya program BOS. Namun, masih sangat sedikit orangtua yang tahu informasi yang lebih rinci tentang BOS, terutama menyangkut jumlah dana BOS per siswa serta penggunaannya, sehingga dikhawatirkan pengelolaan dana BOS tidak sesuai dengan alokasi penggunaan dana yang dimaksud oleh pemerintah.

Menurut penelitian Indonesia Corruption Watch (ICW), Febri Diansyah, secara nasional dengan sampel sekolah 3.237 buah pada 33 provinsi ditemukan nilai penyimpangan dana BOS lebih kurang Rp 28 miliar. Rata-rata penyimpangan setiap sekolah mencapai Rp 13,6 juta dan terjadi pada 2.054 atau 63,5 persen dari total sampel sekolah yang diaudit. Data kejaksaan dan kepolisian seluruh Indonesia periode 2004-2009 berhasil menindak 33 kasus korupsi terkait dengan dana operasional sekolah, termasuk dana BOS. Kerugian negara dari kasus ini lebih kurang Rp 12,8 miliar. Faktor penyebab penyimpangan dana BOS di tingkat sekolah, salah satu adalah rendahnya transparansi, akuntabilitas, dan partisipasi warga atas pengelolaannya.

Menurut Tuanakotta (2007), mereka yang terlibat dalam perbuatan curang didorong oleh interaksi antara kekuatan-kekuatan dalam kepribadian individu dan lingkungan eksternal. Kekuatan-kekuatan tersebut diklasifikasi ke dalam tiga kategori utama: (1) tekanan situasional; (2) kesempatan dan; (3) karakteristik (integritas) pribadi. Dikatakan oleh Mulyadi (2011), kecurangan itu sendiri dikenal dengn istilah fraud di sektor publik, yang di Indonesia dikenal dengan istilah korupsi, yang antara lain merupakan tindakan melawan hukum dan memperkaya diri sendiri atau orang lain, yang mengakibatkan kerugian Negara.

Peran kepala sekolah terhadap terjadinya fraud ini cukup besar. Pada kondisi ini diperlukan sikap etis dan perilaku etis dari kepala sekolah sebagai pengelola dana BOS. Peran yang dimaksudkan disini adalah satu set perilaku dimana orang atau kelompok mengharapkan dari orang lain. Ada bermacam masalah peran dalam dinamika suatu kelompok (Kinicki dan Kreitner 2001) yakni kelebihan peran (role overload), konflik peran (role conflict), ambiguitas peran (role ambiguity). Kinicki dan Kreitner selanjutnya menyatakan bahwa konflik peran yang dialami oleh seseorang bisa jadi disebabkan oleh nilainilai internal (prinsip moral), etika, standar pribadi yang berbenturan dengan harapan orang lain, dan masalah kepemimpinan. Penelitian 
yang dilakukan oleh Rebele dan Michaels 1990, Mathieu dan Zajac 1990, Jones dan Hiltebeitel 1995, Yetmar, Cooper dan Franks 1999, Yetmar dan Eastman 2000, Koh dan Boo 2001 telah menguji beberapa anteseden dari konflik peran dan konsekuensinya terhadap perilaku etis.

Analisis terhadap sikap etis dalam profesi menunjukkan bahwa seseorang merasa memiliki kesempatan untuk melakukan tindakan tidak etis akibat adanya tekanan dari lingungan (Mintz, 1995). Studi tentang etika merupakan hal penting dalam rangka pengembangan dan peningkatan peran profesi guru, terutama bila dikaitkan dengan rawannya profesi ini terhadap perilaku tidak etis dalam pengelolaan dana BOS. Untuk itulah diperlukan pemahaman yang baik tentang penyebab perilaku etis. Pemahaman yang baik tentang anteseden perilaku etis dan konsekuensinya terhadap kepuasan kerja akan memudahkan bagi organisasi untuk meningkatkan kualitas sumber daya manusianya, dalam hal ini kepala sekolah. Penelitian yang dilakukan secara parsial oleh Ziegenfuss dan Singhapakdi 1994, Jones dan Hiltebeitel 1995, Weeks et al. 1999, Yetmar, Cooper dan Franks 1999, Yetmar dan Eastman 2000, Koh dan Boo 2001, Oz 2001 mengonfirmasi berbagai anteseden perilaku etis.

Menurut Kinicki dan Kreitner (2001) dan Hunt dan Vitell (1986), perilaku etis dan tidak etis adalah produk dari kombinasi yang rumit dari berbagai pengaruh. Individu mempunyai kombinasi unik dari karakterisik personalitas, nilai-nilai, prinsip-prinsip moral, pengalaman pribadi dengan penghargaan dan hukuman, sejarah hukuman kesalahan yang dilakukan (history of reinforcement), dan gender. Ada tiga sumber utama pengaruh atas harapan peran etis seseorang. Pertama adalah pengaruh budaya individu tersebut. Pengaruh budaya termasuk latar belakang keluarga, pendidikan, agama, media/hiburan. Kedua adalah pengaruh organisasi. Pengaruh organisasi dapat dalam bentuk kode etik, budaya organisasi, model peran (panutan), tekanan yang dirasakan untuk mencapai hasil, dan sistem penghargaan dan hukuman. Ketiga adalah pengaruh politik, hukum dan ekonomi. Beberapa bukti empiris sebelumnya telah menguji sebagian model di atas, seperti Bernardi et al. (1997), Eynon et al. (1997), Ziegenfuss dan Singhapakdi (1994), Weeks et al.(1999), Cohen et al. (1998), Jones dan Hiltebeitel (1995).

Dari uraian di atas peneliti ingin mengetahui pengaruh penerapan Good Corporate Governance terhadap Perilaku Etis dalam pengelolaan Dana Bantuan OPerasional Sekolah (BOS) pada SMP di Kota Malang.

\section{TINJAUAN PUSTAKA Perilaku Etis}

Etika merupakan filsafat atau pemikiran kritis dan mendasar tentang ajaran dan pandangan moral (Suseno, 1987). Etika juga merupakan tingkah laku atau aturan-aturan tingkah laku yang diterima dan digunakan oleh individual atau suatu golongan tertentu (Khomsiyah dan Indriantoro, 1998). Etika merupakan pedoman, atau ukuran berperilaku yang tercipta melalui konsensus atau keagamaan atau kebiasaan yang didasarkan pada nilai baik dan buruk (Desriani, 1993).

Menurut Griffin dan Ebert (2006) pengertian "etika" merupakan keyakinan mengenai tindakan yang benar dan yang salah, atau tindakan yang 
baik dan yang buruk, yang mempengaruhi hal lainnya. Perilaku etis adalah perilaku yang sesuai dengan norma-norma sosial yang diterima secara umum sehubungan dengan tindakan-tindakan yang benar dan baik. Perilaku etis ini dapat menentukan kualitas individu (karyawan) yang dipengaruhi oleh faktorfaktor yang diperoleh dari luar yang kemudian menjadi prinsip yang dijalani dalam bentuk perilaku.

Faktor-faktor yang mempengaruhi perilaku etis yaitu: (1) Budaya organisasi. Budaya organisasi merupakan sistem makna bersama yang dianut oleh anggota-anggota yang membedakan organisasi itu dari organisasi yang lain. Dengan demikian budaya organisasi adalah nilai yang dirasakan bersama oleh anggota organisasi yang diwujudkan dalam bentuk sikap perilaku pada organisasi. (2) Kondisi politik. Kondisi politik merupakan rangkaian asas atau prinsip, keadaan, jalan, cara atau alat yang akan digunakan untuk mencapai tujuan. (3) Perekonomian global. Perekonomian global merupakan kajian tentang pengurusan sumber daya materian individu, masyarakat, dan negara untuk meningkatkan kesejahteraan hidup manusia

Etika merupakan nilai-nilai tingkah laku atau aturan-aturan tingkah laku yang diterima dan digunakan oleh seseorang atau profesi yang meliputi kepribadian, kecakapan professional, tanggung jawab, pelaksanaan kode etik, dan penafsiran dan penyempurnaan kode etik.

\section{Dana BOS}

Pengertian Bantuan Operasional Sekolah adalah besarnya biaya yang diperlukan rata-rata siswa tiap tahun, sehingga mampu menunjang proses belajar mengajar sesuai dengan standar pelayanan yang telah ditetapkan. Dana BOS adalah program Pemerintah berupa pemberian dana langsung kepada Sekolah yang besarnya dihitung dari jumlah siswa masing-masing sekolah.

Bantuan dana BOS mempunyai 2 fungsi yang dapat digunakan sekolah untuk: (a) Dari sisi penerimaan (revenue) digunakan untuk membebaskan (fee waive) dan/atau memberikan potongan (discount fee) kepada siswa miskin dari kewajiban membayar tagihan biaya sekolah seperti iuran sekolah/sumbangan pembangunan pendidikan (SPP)/uang komite, biaya ujian, biaya praktek dan sebagainya. Jumlah siswa yang dibebaskan atau mendapat potongan biaya pendidikan sesuai dengan kebijakan (diskresi) sekolah dengan mempertimbangkan faktor jumlah siswa miskin yang ada, dana yang diterima dan besarnya biaya sekolah. (b) Dari sisi pengeluaran (expediture) dapat digunakan oleh sekolah untuk memenuhi kebutuhan biaya operasional sekolah non personalia dengan jenis pengeluaran atau biaya sebagaimana diatur Permendiknas No. 69 Tahun 2009.

Bantuan dana BOS bertujuan untuk memberikan dorongan dan motivasi kepada sekolah, masyarakat dan Pemerintah Daerah untuk memberikan kesempatan kepada siswa miskin mengikuti pendidikan di tiap jenjang pendidikan. Oleh karena itu, perlu dicari alternatif pembiayaan untuk memenuhi kebutuhan biaya pendidikan siswa miskin dengan cara melibatkan peran pemda melalui BOS Daerah dan atau menerapkan subsidi silang. 


\section{Good Corporate Governance}

Dua teori utama yang terkait dengan corporate governance adalah stewardship theory dan agency theory (Chinn,2000; Shaw,2003). Stewardship theory dibangun di atas asumsi filosofis mengenai sifat manusia yakni bahwa manusia pada hakekatnya dapat dipercaya, mampu bertindak dengan penuh tanggung jawab, memiliki integritas dan kejujuran terhadap pihak lain. stewardship theory memandang manajemen sebagai dapat dipercaya untuk bertindak dengan sebaik-baiknya bagi kepentingan publik maupun stakeholder.

Sementara itu, agency theory yang dikembangkan oleh Michael Johnson dalam Daniri (2005), memandang bahwa manajemen perusahaan sebagai "agents" bagi para pemegang saham, akan bertindak dengan penuh kesadaran bagi kepentingannya sendiri, bukan sebagai pihak yang arif dan bijaksana serta adil terhadap pemegang saham. Dalam perkembangan selanjutnya, agency theory mendapat respon lebih luas karena dipandang lebih mencerminkan kenyataan yang ada. Berbagai pemikiran mengenai corporate governance berkembang dengan bertumpu pada agency theory di mana pengelolaan dilakukan dengan penuh kepatuhan kepada berbagai peraturan dan ketentuan yang berlaku.

Good corporate governance (GCG) secara definitif merupakan sistem yang mengatur dan mengendalikan perusahaanyang menciptakan nilai tambah (value added) untuk semua stakeholder (Monks, 2003). Ada dua hal yang ditekankan dalam konsep ini, pertama, pentingnya hak pemegang saham untuk memperoleh informasi dengan benar dan tepat pada waktunya dan, kedua, kewajiban perusahaan untuk melakukan pengungkapan (disclosure) secara akurat, tepat waktu, transparan terhadap semua informasi kinerja perusahaan, kepemilikan, dan stakeholder.

Ada empat komponen utama yang diperlukan dalam konsep good corporate governance, (Kaen, 2003; Shaw, 2003) yaitu fairness, transparency, accountability, dan responsibility. Keempat komponen tersebut penting karena penerapan prinsip good corporate governance secara konsisten terbukti dapat meningkatkan kualitas laporan keuangan dan juga dapat menjadi penghambat aktivitas rekayasa kinerja yang mengakibatkan laporan keuangan tidak menggambarkan nilai fundamental perusahaan.

Secara umum terdapat lima prinsip dasar dari good corporate governance yaitu: (1) Transparency (keterbukaan informasi), yaitu keterbukaan dalam melaksanakan proses pengambilan keputusan dan keterbukaan dalam mengemukakan informasi materiil dan relevan mengenai perusahaan. (2) Accountability (akuntabilitas), yaitu kejelasan fungsi, struktur, sistem, dan pertanggungjawaban organ perusahaan sehingga pengelolaan perusahaan terlaksana secara efektif. (3) Responsibility (pertanggungjawaban), yaitu kesesuaian (kepatuhan) di dalam pengelolaan perusahaan terhadap prinsip korporasi yang sehat serta peraturan perundangan yang berlaku. (4) Independency (kemandirian), yaitu suatu keadaan dimana perusahaan dikelola secara profesional tanpa benturan kepentingan dan pengaruh/tekanan dari pihak manajemen yang tidak sesuai dengan peraturan dan perundangan-undangan yang berlaku dan prinsip-prinsip korporasi yang sehat. (5) Fairness (kesetaraan dan kewajaran), yaitu perlakuan yang adil dan setara di dalam memenuhi hak-hak stakeholder yang timbul berdasarkan perjanjian serta peraturan perundangan yang berlaku. 
Esensi dari corporate governance adalah peningkatan kinerja perusahaan melalui supervisi atau pemantauan kinerja manajemen dan adanya akuntabilitas manajemen terhadap pemangku kepentingan lainnya, berdasarkan kerangka aturan dan peraturan yang berlaku.

Menurut landasan teori mengenai transparansi, akuntabilitas, pertanggungjawaban, kemandirian, dan kesetaraan maka dapat disusun kerangka pikir gambar 3 sebagai berikut :

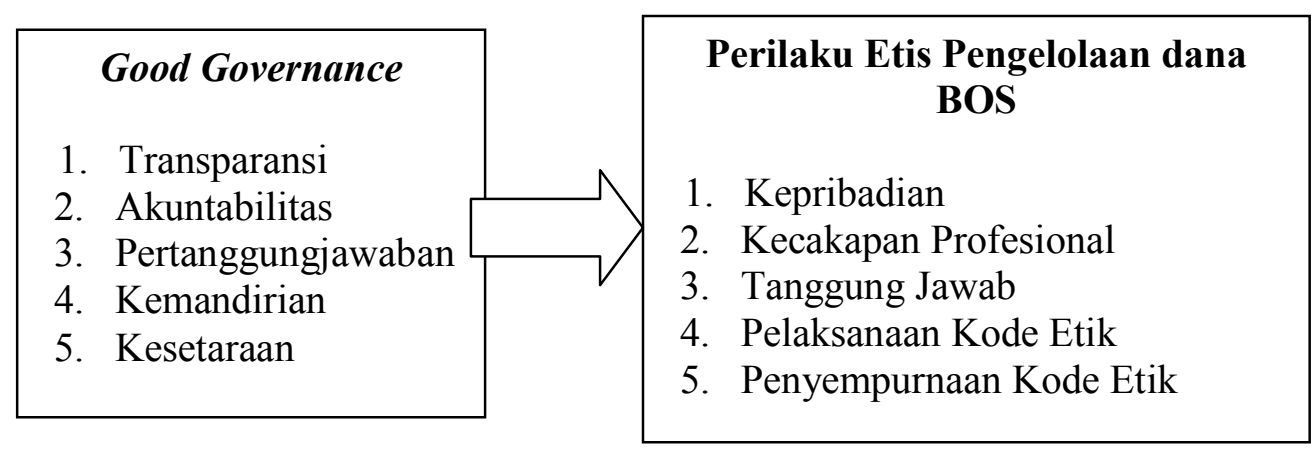

Gambar 1 : Kerangka Pikir

Dari kerangka pikir tersebut disusun kerangka konseptual pemikiran sebagai berikut:

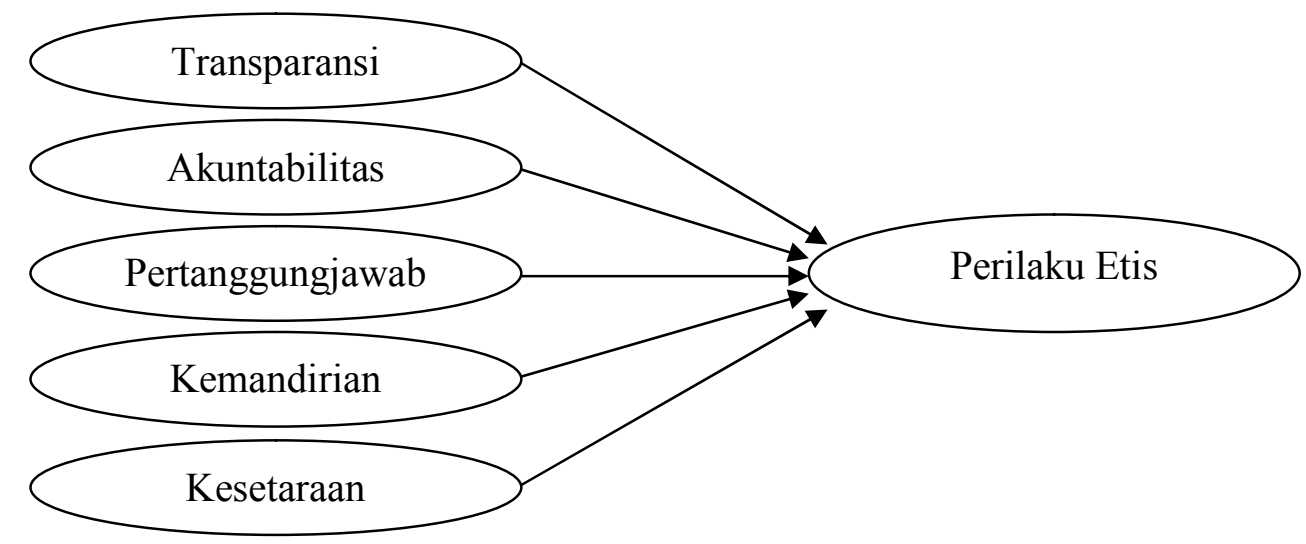

Gambar 2 : Kerangka Konseptual Penelitian

Bedasarkan kerangka pemikiran dan rumusan masalah di atas, maka dikembangkan hipotesis penelitian sebagai berikut :

1. Transparansi berpengaruh secara positif dan signifikan terhadap Perilaku Etis pengelolaan Dana Bantuan Operasional Sekolah di SMP Kota Malang

2. Akuntabilitas berpengaruh secara positif dan signifikan terhadap Perilaku Etis pengelolaan Dana Bantuan Operasional Sekolah di SMP Kota Malang 
3. Pertanggungjawaban berpengaruh secara positif dan signifikan terhadap Perilaku Etis pengelolaan Dana Bantuan Operasional Sekolah di SMP Kota Malang

4. Kemandirian berpengaruh secara positif dan signifikan terhadap Perilaku Etis pengelolaan Dana Bantuan Operasional Sekolah di SMP Kota Malang

5. Kesetaraan berpengaruh secara positif dan signifikan terhadap Perilaku Etis pengelolaan Dana Bantuan Operasional Sekolah di SMP Kota Malang

\section{METODE}

Desain penelitian ini adalah survey. Data penelitian yang dibutuhkan adalah data primer dalam bentuk persepsi responden (subjek) penelitian. Pengambilan data menggunakan survey langsung dan instrumen yang di gunakan adalah kuesioner (angket). Penelitian ini dilakukan pada guru di Kota Malang. Adapun sampelnya dipilih melalui teknik Simple Random Sampling. Teknis analisis data yang digunakan untuk menjawab rumusan masalah dalam penelitian ini adalah Analisis Regresi Linear Berganda.

\section{PEMBAHASAN}

\section{Profile Responden}

Di antara 90 responden, $39 \%$ atau 35 orang adalah perempuan dan $61 \%$ atau 55 orang adalah laki-laki. Mayoritas responden (53\%) atau 48 orang berada dalam kelompok umur antara 36-40. Di sisi lain, 27\% dari responden usia jatuh di kisaran 30 sampai 35 tahun sebanyak 25 orang, dan sisanya 18\% atau sekitar 17 orang berusia di atas 40 tahun. Mayoritas responden memiliki gelar sarjana (71,5\%) atau 64 orang, diikuti oleh responden memiliki gelar master $(28,5 \%)$ sebanyak 26 orang.

\section{Test of Hypotheses}

Uji korelasi antara transparansi (x1), akuntabilitas (x2), tanggung jawab (x3), independensi (x4), keadilan (x5) dan perilaku etis (y) ditunjukkan pada tabel 1 di bawah ini. Analisis regresi berganda digunakan untuk menguji H1, H2, H3, H4 dan H5. Hasil pengujian diilustrasikan pada Tabel 2.

Table 1. Result of Pearson Correlation Coeffecient Analysis

\begin{tabular}{|l|l|l|l|l|l|l|}
\hline Var & $\mathrm{X} 1$ & $\mathrm{X} 2$ & $\mathrm{X} 3$ & $\mathrm{X} 4$ & $\mathrm{X} 5$ & $\mathrm{Y}$ \\
\hline $\mathrm{X} 1$ & 1 & & & & & \\
\hline $\mathrm{X} 2$ & $0.674^{* *}$ & 1 & & & & \\
\hline $\mathrm{X} 3$ & $0.754^{* *}$ & $0.852^{* *}$ & 1 & & & \\
\hline $\mathrm{X} 4$ & $0.751^{* *}$ & $0.852^{* *}$ & $0.855^{* *}$ & 1 & & \\
\hline $\mathrm{X} 5$ & $0.762^{* *}$ & $0.840^{* *}$ & $0.876^{* *}$ & $0.930^{* *}$ & 1 & \\
\hline $\mathrm{Y}$ & $0.781^{* *}$ & $0.932^{* *}$ & $0.947^{* *}$ & $0.929^{* *}$ & $0.919^{* *}$ & 1 \\
\hline
\end{tabular}

Note : ${ }^{* *}$ Correlation is significant at the 0.01 level (2-tailed) 
166 MODERNISASI, Volume 10, Nomor 3, Oktober 2014

Table 2. Results of multiple regression analysis

\begin{tabular}{|c|l|l|l|c|}
\hline $\begin{array}{c}\text { Dependent } \\
\text { variable }\end{array}$ & \multicolumn{1}{|c|}{$\begin{array}{c}\text { Independent } \\
\text { variable }\end{array}$} & Std. Beta & $\mathrm{t}$ & Sig. \\
\hline \multirow{4}{*}{$\begin{array}{c}\text { Ethical } \\
\text { Behaviour }\end{array}$} & Transparancy & 0.089 & 2.235 & 0.028 \\
\cline { 2 - 5 } & Accountability & 0.325 & 8.741 & 0.000 \\
\cline { 2 - 5 } & Responsibility & 0.363 & 9.247 & 0.000 \\
\cline { 2 - 5 } & Independency & 0.243 & 4.833 & 0.000 \\
\cline { 2 - 5 } & Fairness & 0.027 & 0.561 & 0.576 \\
\cline { 2 - 5 } & $\mathrm{R}$ & \multicolumn{3}{|c|}{0.987} \\
\cline { 2 - 5 } & $\mathrm{R}^{2}$ & \multicolumn{3}{|c|}{0.979 .843} \\
\hline & F hitung & \multicolumn{3}{|c|}{0.000} \\
\hline & Sig. F & \multicolumn{3}{|c|}{} \\
\hline
\end{tabular}

Analisis regresi berganda ini digunakan untuk melihat efek dari penerapan tata kelola perusahaan yang baik (good corporate governance) pada perilaku etis dalam pengelolaan dana Bantuan Operasional Sekolah. Hasil pada tabel 2 menunjukkan bahwa keadilan (fairness) mempunyai pengaruh positif tetapi tidak signifikan terhadap perilaku etis $(\beta=0,027, \mathrm{p}>\alpha=0,05)$. Di sisi lain, menunjukkan bahwa transparansi, akuntabilitas, responsibilitas, independensi memiliki pengaruh yang signifikan dan positif terhadap perilaku etis. Masingmasing memiliki nilai $(\beta=0,089, \mathrm{p}<0,05 ; \beta=0,325, \mathrm{p}<0,05 ; \beta=0.363, \mathrm{p}<0,05$; $\beta=0,243, \mathrm{p}<0,05)$. Dengan demikian H1, H2, H3 dan H4 didukung, sementara H5 tidak didukung.

\section{KESIMPULAN Kesimpulan}

Sebagai kesimpulan, dapat dipertimbangkan bahwa tata kelola perusahaan yang baik (GCG) sebagai kumpulan fitur penting yang membentuk sebuah organisasi. Oleh karena itu, untuk memahami identitas perusahaan, harus mengetahui peran tata kelola perusahaan yang baik pada waktu yang sama. GCG berfungsi sebagai identitas dan juga perencanaan strategis organisasi dengan tidak memberikan keuntungan ekonomi, tetapi juga berkontribusi terhadap pertumbuhan dan perkembangan masyarakat dan lingkungan. Dengan demikian, para pemangku kepentingan dapat menggunakan GCG sebagai cara untuk memahami identitas organisasi; dan organisasi juga dapat menggunakannya sebagai alat untuk membangun identitas organisasi mereka.

\section{Saran}

Temuan dari studi ini menarik perhatian beberapa arah untuk penelitian lebih lanjut yang akan dilakukan dalam bidang ini. Satu catatan penting adalah bahwa penelitian selanjutnya harus menggunakan konstruksi yang diwakili oleh variable yang multi-dimensi untuk menangkap esensi dari sebuah model penelitian. Perhatian harus dilakukan sebagai penguatan yang memiliki dimensi bervariasi dan peneliti harus menyesuaikan kesesuaian masing-masing dimensi berdasarkan tujuan penelitian. 
Studi selanjutnya harus menggunakan kedua metode kuantitatif dan kualitatif karena hal ini dapat menyajikan informasi yang lebih mendalam dan mengatasi kelemahan masing-masing metodologi.

Penelitian ini juga menunjukkan bahwa penelitian selanjutnya mencakup wilayah yang lebih luas dari sektor publik di bidang pendidikan. Karena tata kelola perusahaan yang baik tidak hanya terbatas pada sektor publik di bidang pendidikan, investigasi serupa dapat direplikasi dalam kegiatan sektor publik lainnya seperti bank, pemerintah daerah, rumah sakit, dan industri lainnya. Replikasi penelitian ini dimungkinkan karena praktik tata kelola perusahaan yang baik sejalan dengan sifat pelayanan yang dilakukan oleh sector publik. Studi semacam ini relatif masih baru di Indonesia, studi selanjutnya akan memperkaya tubuh pengetahuan tentang sektor publik di Indonesia.

\section{DAFTAR PUSTAKA}

Arikunto, Suharsimi. 2002, Prosedur Penelitian (Suatu pendekatan Praktik), Rieneka Cipta, Jakarta.

Asian Development Bank, 1999, Governance : Sound Development Management di akses 27 Juli 2012; 11.15 wib)

Asian Development Bank, Public Administration in the 21-st Century (artikel di internet, di akses 27 Juli 2012; $12.30 \mathrm{wib})$

Bastian, Indra, 2007, Akuntansi Pendidikan, Penerbit Erlangga, Jakarta.

Budiardjo, Miriam, 2000, Menggapai Kedaulatan untuk Rakyat, Mizan Bandung.

Contoh-kuesioner-skripsi (http://contohskripsi.net/diakses 30 Juli 2012; 11.43)

Dewan Standar Akuntansi Keuangan, 2010, Pelaporan Keuangan Entitas Nirlaba, Ikatan Akuntansi Indonesia, Jakarta

Griffith, A.I. 1995. Coordinating Family and School: Mothering for Schooling. Education Policy Analysis Archives, (Online), Vol 3 no.1, (http://olam.ed.asu.edu/epaa/ diakses 12 Februari 2006)

Headington, Rita, 2000, Monitoring, Assesment, Recording, reporting and Accountability, Meeting the Standards. David Fulton Publishers, London

Hendrawan Ronny, 2011, Analisi Penerapan PSAK No.45 tentang Pelaporan Keuangan Organisasi Nirlaba pada Rumah Sakit Berstatus Badan Layanan Umum, Skripsi, Semarang

Jalal Fasli \& Supriadi Dedi, 2001, Reformasi Pendidikan dalam Konteks Otonomi Daerah, AdiCita, Yogyakarta. 
168 MODERNISASI, Volume 10, Nomor 3, Oktober 2014

Kuesioner-dan-buku-pedoman (http://demografi.bps.go.id/diakses 30 Juli 2012; 12.15)

Konsep-Akuntabilitas (http:/www.scribd.com/doc/91725005/KonsepAkuntabilitas/diakses 5 Agustus 2012; 13:06 wib)

Karding, Abdul Kadir, 2008, Tesis Evaluasi Pelaksanaan Program Bantuan Operasional Sekolah (BOS), Universitas Diponegoro, Semarang.

Kaen, Fred. R, A Blueprint for Corporate Governance: Stregy, Accountability, and the Preservation of Shareholder Value, AMACOM, USA. 2003.

Monks, Robert A.G, dan Minow, N, Corporate Governance $3^{\text {rd }}$ Edition, Blackwell Publishing, 2003.

Mabadik.wordpress.com/2010/07/10/teknik-analisis-data-kuantitatif

Mardiasmo, 2002, Otonomi dan Manajemen Keuangan Daerah, Penerbit Andi,Yogyakarta. , 2002, Akuntansi Sektor Publik, Penerbit Andi, Yogyakarta.

Mardiasmo, artikel Pewujudan Transparansi dan Akuntabilitas Publik MelaluiAkuntansi Sektor Publik: Suatu Sarana Good Governance dalam JURNALAKUNTANSI PEMERINTAH, Vol. 2, No. 1, Mei 2006.

Meuthia, 2000, HAM : Penyelenggaraan Negara Yang Baik dan Masyarakat Warga, KOMNAS HAM, Jakarta.

Olssen Mark, Codd, \& Anne-Marie O'Neill. (2004). Education Policy:Globalization, Citizenship and Democracy. London, Thousand Oeaks. NewDelhi: Sage Publications

Pedoman BOS 2012

Peraturan Mendagri No.62 Tahun 2011, Pedoman Pengelolaan BOS

Peraturan Mendikbud RI No.51 Tahun 2011, Juknis Penggunaan Dana BOS dan Laporan Keuangan BOS Tahun 2012

Peraturan Pemerintah No 19 Tahun 2005 tentang Standar Nasional Pendidikan

Peters, B.Guy, 2000, The Politics of Bureaucracy, Routledge, London.

Sarwoko, Endi, 2007, Buku Ajar Statistik Inferensial, Fakultas Ekonomi Universitas Kanjuruhan, Malang. 
Sinaga, Jamason, 2005 Kerangka Konseptual Standar Akuntansi Pemerintah, (http://www.ksap.org/Riset\&Artikel/)

Slamet PH. (2005).Handout Kapita Selekta Desentralisasi Pendidikan diIndonesia. Jakarta:Direktorat Pendidikan Lanjutan Pertama, Depdiknas RI

Subroto, Agus, 2009, Tesis Akuntabilitas Pengelolaan Dana Desa, Universitas Diponegoro, Semarang.

Sugiyono, 2006, Metode penelitian kuantitatif, kualitatif dan $R \& D$, Alfabeta, Bandung

Sugiyono, 2008, Metode penelitian administrasi dilengkapi metode $R \& D$, Alfabeta, Bandung

Teknik-analisis-data skripsimahasiswa.blogspot.com/) Tizarrahmawan. wordpress. com/2009/11/24/selayang-pandang-analisa-dataKualitatis-dan kuantitatif/(28/7/12, 14:32)

Undang-undang No 20 Tahun 2003 tentang Sistem Pendidikan Nasional. Jakarta: CV Tamita Utama 